\title{
IMPLEMENTASI PRINSIP-PRINSIP GOOD CORPORATE GOVERNANCE DI KSPPS BMT SALAFIYAH SUKOREJO SUMBEREJO BANYUPUTIH KABUPATEN SITUBONDO
}

\author{
Oleh: \\ Imroatus Sholiha \\ Universitas Ibrahimy Situbondo, Indonesia \\ Iim_54@yahoo.co.id
}

\begin{abstract}
:
A Cooperative is a financial institution that aims to prosper its members. In addition to conventional cooperatives, there are now sharia cooperatives which in carrying out their operations use sharia principles. KSPPS BMT Salafiyah is one of them, KSPPS BMT Salafiyah is a savings and loan cooperative and sharia financing owned by the Salafiyah Syafi'iyah Islamic Boarding School Sukorejo. BMT is the closest Islamic financial institution to the community. And to maintain public trust in BMT, transparency, accountability, responsibility, professionalism, and fairness are needed in carrying out its operations. This study discusses Good Corporate Governance (GCG) in which there are 5 principles. The focus of the problem in this research are: first, how is the implementation of GCG principles in KSPPS BMT Salafiyah Sukorejo Sumberejo Banyuputih Situbondo?; second, what are the obstacles faced in implementing the principles of GCG in KSPPS BMT Salafiyah Sukorejo Sumberejo Banyuputih Situbondo? The purpose of this research is to describe how the implementation of GCG principles in KSPPS BMT Salafiyah and what are the obstacles in implementing GCG principles in KSPPS BMT Salafiayah Sukorejo Sumberejo Banyuputih Situbondo.

This study uses a qualitative descriptive method and uses the instruments of observation, interviews, and documentation. Meanwhile, the data analysis uses descriptive analysis technique, which describes qualitatively when conducting research, with an emphasis on the Implementation of Good Corporate Governance (GCG) Principles at KSPPS Salafiyah Sukorejo Sumberejo Banyuputih Situbondo.

The result of this research is that KSPPS BMT Salafiyah implements 5 principles of GCG, namely transparency, accountability, responsibility, professionalism, and fairness. And for the obstacles faced in implementing GCG, KSPPS BMT Salafiyah experienced obstacles in internal factors, namely the ebb and flow of employee discipline in carrying out their duties or obligations, the effort they made was to apply rules to employees to come to the office before 8 o'clock and give
\end{abstract}


rewards to employees with high discipline.

Keyword: Implementation, Good Corporate Governance (GCG), BMT

\section{A. Pendahuluan}

Pada dekade yang serba modern ini keberadaan bank sangat dibutuhkan oleh masyarakat secara luas. Seakan masyarakat tidak bisa menerima alasan kenapa bank harus ditiadakan. Bank merupakan satu kesatuan yang tidak bisa dipisahkan dengan dunia bisnis dan ekonomi. Adanya bisnis, lembaga keuangan dan masyarakat merupakan siklus yang saling melengkapi dan menganut teori simbiosis mutualisme. Bank merupakan salah satu lembaga keuangan yang ada di Indonesia.

Di Indonesia, pelopor perbankan syariah adalah Bank Muamalat Indonesia. Bediri tahun 1991, bank ini diprakarsai oleh Majelis Ulama Indonesia (MUI) dan pemerintah serta dukungan dari Ikatan Cendekiawan Muslim Indonesia (ICMI) dan beberapa pengusaha muslim. ${ }^{1}$

Dukungan terhadap perbankan syariah semakin kuat dengan disahkannya Undang-Undang No. 21 tahun 2008 tentang perbankan syariah. Pada oktober 2009, telah ada 6 BUS dan 25 UUS dengan total asset sebesar Rp. 59,68 triliun (2,4 \% dibandingkan dengan asset bank konvensional) dan berhasil menyerap lebih dari 17 ribu pekerja. Data ini belum termasuk Bank Pembiayaan Rakyat Syariah (BPRS).2

Saat ini bukan hanya lembaga keuangan berskala besar yang mengalami kemajuan. Namun lembaga keuangan yang memilki skala kecil pun mulai menunjukkan perkembangan seperti Baitul Maal Wattamwil. BMT adalah lembaga keuangan syariah non bank yang lebih dominan pada peningkatan kesejahteraan anggota. Selain itu BMT sangat berperan penting dalam pengembangan perekonomian di Indonesia khususnya pada sektor usaha mikro kecil dan menengah (UMKM). Kehadiran BMT diharapkan mampu menjadi sarana dalam menyalurkan dana untuk usaha bisnis kecil dengan mudah dan bersih, karena didasarkan pada kemudahan dan bebas riba/bunga, memperbaiki / meningkatkan taraf hidup masyarakat bawah, lembaga keuangan alternatif yang mudah diakses oleh masyarakat bawah dan bebas riba/ bunga, lembaga untuk

${ }^{1}$ Khaerul Umam, Manajemen Perbankan Syariah, (Bandung: Pustaka Setia, 2013),

${ }^{2}$ Ibid, 23

$162 \mid$ JURNAL LISAN AL-HAL 
memberdayakan ekonomi umat, mengentaskan kemiskinan, dan meningkatkan produktifitas. ${ }^{3}$

Sejalan dengan perkembangan BMT yang semakin meningkat, maka akan menyebabkan semakin membesarnya tingkat kompetitif dalam pengelolaan sistem operasional yang dijalankan oleh masing-masing BMT yang ada di Indonesia. Tidak terkecuali BMT Salafiyah Syafi'iyah Sukorejo Banyuputih Situbondo. Atau bisa disebut juga KSPPS BMT (Koperasi Simpan Pinjam Pembiayaan Syariah) Salafiyah Syafi'iyah Sukorejo Sumberejo Banyuputih Situbondo. Dalam operasionalnya KSPPS BMT Salafiyah Syafi'iyah ini memberikan pelayanan yang bergerak di bidang penyediaan jasa simpanan dan pembiayaan bagi para nasabah. Keberadaan KSPPS BMT Salafiyah Syafi'iyah ini sangat diperlukan karena bisa menyentuh masyarakat kalangan bawah secara langsung dan lebih dekat dengan masyarakat. Dengan tempat operasi yang strategis yang berada di pinggir jalan pantura mengakibatkan KSPPS BMT Salafiyah Syafi'iyah mudah dikenal masyarakat dan lebih dijangkau keberadaannya.

Namun bukan berarti dengan kemudahan akses yang dimiliki oleh KSPPS BMT Salafiyah Syafi'iyah lantas membuat lembaga tersebut tidak melakukan perbaikan-perbaikan dalam melakukan operasionalnya. Perbaikan- perbaikan sistem, layanan, marketing harus terus dilakukan demi keberlangsungan lembaga tersebut. Sehingga penting bagi lembaga tersebut menerapkan Good Corporate Governance (GCG).Sebuah teori yang mengajarkan tentang keprofesionalan lembaga dalam menjalankan operasionalnya. Menurut Komite Cadbury yang dituangkan dalam jurnal “ MD Membangun Profesionalisme Keilmuan" Good Corporate Governance (GCG) adalah sistem yang mengarahkan dan mengendalikan perusahaan dengan tujuan agar mencapai keseimbangan antara kekuatan kewenangan yang diperlukan oleh perusahaan, untuk menjamin kelangsungan eksistensinya dan pertanggungjawaban kepada Stakeholder. ${ }^{4}$ Ada dua hal dalam konsep Good Corporate Governance. Pertama, pentingnya hak pemegang saham untuk memperoleh informasi dengan benar dan tepat pada waktunya. Kedua, kewajiban perusahaan untuk melakukan pengungkapan (disclosure) secara akurat, tepat waktu, transparan, terhadap semua informasi kinerja perusahaan, kepemilikan dan 2004), 42

${ }^{3}$ Heri Sudarsono, Bank Dan Lembaga Keuangan Syariah, (Yogyakarta: Ekonisia,

4 Komite Cadbury, The Business Roundtable, Statement Untuk Corporate Governance, (Washington DC:tnp, 1997), 1 dalam Mishardi Wilamarta, 40 dan dituangkan Hana Septi Kuncaraningsih dan M. Rasid Ridla, Good Corporate Governance Dalam Meningkatkan Kepuasan Muzakki di Badan Amil Zakat Nasional, 99. 
stakeholder. Penerapan Good Corporate Governance bertujuan untuk mengoptimumkan tingkat profitabilitas dan nilai perusahaan dalam jangka waktu panjang tanpa mengabaikan kepentingan stakeholder lainnya. ${ }^{5}$ Dalam sebuah lembaga kecil seperti KSPPS BMT Salafiyah Syafi'iyah Sukorejo ketransparanan, keprofesionalan buka hanya diperuntukkan untuk pemegang saham. Akan tetapi berlaku bagi semua lini yang ada didalamnya. Bagaimana tanggung jawab karyawan, manager dalam menjalankan tugasnya?. Bagaimana melayani nasabah dengan baik?. Bagaimana mengelola dana yang ada? Dan masih banyak lagi yang lainnya.

Maju atau tidaknya sebuah lembaga ditentukan oleh pengelola yang ada di dalamnya begitu juga dengan KSPPS BMT Salafiyah Syafi'iyah. Di KSPPS BMT Salafiyah Syafi'iyah saat ini sudah bisa membuka beberapa cabang yang ada diluar kota Situbondo, yaitu tepatnya ada di Kabupaten Banyuwangi ada tiga cabang yaitu di kecamatan Kalibaru, Wongsorejo dan Kalipuro. Dan untuk di kabupaten Situbondo ada satu cabang yaitu di Asembagus. Bukan hal yang mudah bagi sebuah lembaga untuk bisa memperluas jangkauannya dalam melayani masyarakat hingga bisa membuka cabang di luar daerah, hal itu memerlukan keseriuasan pengurus, pengelola, dan karyawan dalam menjalankan operasional lembaga tersebut.

Dari awal berdiri nama KSPPS BMT Salafiyah Syafi'iyah adalah UJKS (Unit Jasa Keuangan Syariah) dan masih menginduk pada koperasi Musa'adah sebuah lembaga yang juga dimiliki oleh Pondok Pesantren Salafiyah Sukorejo. Banyak usaha-usaha pesantren yang ada dibawah naungan koponren Musa'adah seperti toko alat bangunan, toko alat tulis kantor, dan banyak lagi usaha-usaha yang lainnya, salah satunya UJKS ini yaitu (Unit Jasa Keuangan Syariah). Kemudian pada tahun 2013 UJKS berubah nama menjadi KJKS BMT Salafiyah dibawah binaan dan pengawasan bidang usaha Pondok Pesantren Salafiyah Syafi'iyah Sukorejo. Kemudian pada tahun 2017 KJKS BMT Salafiyah mampu berdiri sendiri dan bukan dibawah naungan bidang usaha Pondok Pesantren lagi dan berubah nama menjadi KSPPS BMT Salafiyah Syafi'iyah Sukorejo dan memiliki 4 cabang saat ini. Tentu hal ini menjadi prestasi tersendiri bagi lembaga KSPPS BMT Salafiyah Syafi'iyah Sukorejo karena sudah bisa terus bermetamorfosis kearah yang lebih baik dari tahun ketahunnya.

${ }^{5}$ Muda Setia dan Zulkifli, Pengaruh Penerapan Corporate Governanace (GCG) Dan Budaya Organisasi Pengelolaan Zakat Terhadap Motivasi Pembayaran zakat Penghasilan di DIY, Jurnal Kajian Bisnis Vol.2, No. 1, Januari 2018, 51.

$164 \mid$ JURNAL LISAN AL-HAL 
Berangkat dari hal tersebut apakah KSPPS BMT Salafiyah Syafi'iyah ini menjalankan teori Good Corporate Govenance (GCG) atau tidak dalam menjalankan opersionalnya, sehingga bisa eksis dan bisa mengembangkan usahanya hingga saat ini?. Akhirnya peneliti mengangkat judul " Implementasi Prinsip- Prinsip Good Corporate Goverance (GCG) di KSPPS BMT Salafiyah Syafi'iyah Sukorejo Sumberejo Kecamatan Banyuputih Kabupaten Situbondo".

Dengan fokus masalah bagaimana Implementasi Prinsip-Prinsip Good Corporate Governance (GCG) di KSPPS BMT Salafiyah Syafi'iyah Sukorejo Sumberejo Kecamatan Banyuputih Kabupaten Situbondo?Dan apa kendala yang dihadapi dalam mengimplementasikan Prinsip-Prinsip Good Corporate Governance (GCG) di KSPPS BMT Salafiyah Syafi'iyah Sukorejo Sumberejo Kecamatan Banyuputih Kabupaten Situbondo?

\section{B. Metode Penelitian}

Adapun pendekatan penelitian ini menggunakan pendekatan kualitatif, yaitu jenis penelitian yang tidak menggunakan perhitungan. Prosedur penelitian yang dihasilkan data deskriptif berupa kata-kata tertulis atau lisan dari orang-orang atau perilaku yang diamati. Penarikan sampel secara purposif menekankan pada pertimbangan karakteristik tertentu dari subjek penelitiannya. ${ }^{6}$

Penelitian yang digunakan disini adalah pendekatan kualitatif yang bersifat deskriptif yang nantinya hasil penelitian ini diperoleh dari data deskriptif yang berupa Implementasi prinsip-prinsip Good Corporate Governance (GCG) di Unit Koperasi Simpan Pinjam Pembiayaan Syariah (KSPPS) Sukorejo Sumberejo Kecamatan Banyuputih Kabupaten Situbondo. Adapun informan yang disajikan sumber data oleh peneliti adalah:

Pertama, Direktur (Pimpinan). Dalam kamus besar Bahasa Indonesia menyebutkan bahwa, direktur adalah orang yang bertugas memberikan bimbingan melalui pengarahan, nasehat dan bantuan penegasan.7 $^{7}$ Data yang diperoleh: 1) Sejarah berdirinya KSPPS BMT Salafiyah Syafi'iyah, 2) Lokasi KSPPS BMT Salafiyah Syafi'iyah, dan 3) Implementasi GCG dalam hal transparansi, akuntabilitas, responsibilitas, independensi, dan kewajaran dan kesetaraan.

${ }^{6}$ M. Subana, Dasar-Dasar Penelitian Karya Ilmiah, (Bandung: Pustaka Setia, 2001),

7 Tim Penyusun KBBI, Jakarta, Balai Pustaka, 2002, 236.

$$
\begin{array}{l|l}
\text { JURNAL LISAN AL-HAL } & 165
\end{array}
$$


Kedua, Karyawan. Yaitu orang yang melakukan suatu karya atau hasil kerja secara terorganisir dalam lingkungan suatu perusahaan atau unit kerja. Seorang karyawan biasanya melakukan pekerjaan dalam suatu organisasi swasta atau pemerintah dan diberikan imbalan jasa sesuai dengan peraturan yang berlaku ${ }^{8}$. Data yang diperoleh: 1) Aplikasi atau impementasi tentang prinsip GCG, 2) Pemahaman karyawan atau pengelola terhadap prinsip GCG, dan 3) Kendala yang dihadapi dalam mengimplementasikan prinsip GCG.

Ketiga, Nasabah. Yaitu orang atau badan hukum yang mempunyai rekening baik rekening simpanan atau pinjaman pada pihak bank. Sehingga nasabah merupakan orang yang bisa berhubungan dengan atau menjadi pelanggan bank. ${ }^{9}$ Data yang akan diperoleh: 1) Transparansi yang diberikan KSPPS BMT Salafiyah Syafi'iyah, 2) Akuntabilitas yang diberikan KSPPS BMT Salafiyah Syafi'iyah, 3) Resposibilitas yang diberikan KSPPS BMT Salafiyah Syafi'iyah, 4) Profesionalitas yang diberikan KSPPS BMT Salafiyah Syafi'iyah, dan 5) Kewajaran dan kesetaraan yang diberikan KSPPS BMT Salafiyah Syafi'iyah.

Sedangkan metode pengumpulan datanya mengguakan observai, wawancara dan dokumentasi dan metode keabsahan datanya menggunakan triangulasi sumber.

\section{Hasil Penelitian dan Pembahasan}

1. Baitul Maal Wattamwil

Istilah Baitul Maal Wattamwil (BMT) sebenarnya berasal dari dua kata, yaitu Baitul Maal dan Baitu Tamwil. IstilahBaitul Maal berasa dari kata bait dan al maal. Bait artinya bangunan atau rumah, sedangkan al maal adalah harta benda atau kekayaan. Jadi baitul maal dapat diartikan sebagai perbendaharaan (umum atau Negara). Sedangkan baitul maal dilihat ari segi istilah fiqih adalah suatu lembaga atau badan yang bertugas untuk mengurusi kekayaan Negara terutam keuangan, baik yang berkenaan dengan soal pemasukan dan pengelolaan maupun pengeluaran dan lain-lain. ${ }^{10}$

Sedangkan baituttamwil, secara harfiah bait adalah rumah dan attamwil secara harfiah adalah pengembangan harta. Jadi, baitul tamwil

8 Gouzali Saydam, Kamus Istilah Kepegawaian, (Jakarta: Midas Surya Grafindo, 1997), 110.

${ }_{9}^{9}$ M. Nur Rianto Al Arif, Dasar-Dasar Pemasaran Bank Syariah, (Bandung: Alfabeta, 2010), 189.

10Suhrawardi K Lubis, Hukum Ekonomi Islam, (Jakarta: Sinar Grafika, 2000), 114

$166 \mid$ JURNAL LISAN AL-HAL 
adalah suatu lembaga yang melakukan kegiatan pengembangan usahausaha produktif dan investasi dalam meningkatkan kesejahteraan pengusaha mikro melalui kegiatan pembiayaan dan menabung berinvestasi. ${ }^{11}$

a. Asas dan Prinsip Dasar BMT

Baitul Mal Wattamwil (BMT) didirikan dengan berasaskan pada masyarakat yang salaam, yaitu penuh keselamatan, kedamaian, dan kesejahteraan. Prinsip BMT: 1) Ahsan (mutu hasil terbaik), thayyiban (terindah) dan sesuai dengan nilai-nilai salam keselamatan, kedamaian dan kesejahteraan, 2) Barakah, 3) Spiritual communication (penguatan nilai ruhaniyah), 4) Demokrasi, partisipatif, 5) Keadilan sosial dan kesetaraan gender, non diskrimatif, 6) Ramah lingkungan, 7) Peka dan bijak trhadap pengetahuan dan budaya local serta keragaman budaya, dan 8) Keberlanjutan memberdayakan masyarakat dengan meningkatkan kemampuan diri dan lembaga masyarakat. ${ }^{12}$

b. Cara mendirikan koperasi syariah atau BMT

Dalam proses pendirian BMT, perlu memperhatikan beberapa hal, diantaranya: ${ }^{13}$ 1) Harus ada pemrakarsa, motivator yang telahengetahui BMT, pemrakarsa mencoba meluaskan jaringan ke para sahabat dengan menjelaskan tentang BMT dan peranannya dalam mengangkat harkat dan martabat masyarakat, 2) Diantaranya pemrakarsa tersebut kemudian membentuk panitia penyiapan pendirian BMT (P3B) di lokasi yang dimaksud, 3) Selanjutnya P3B mencari modal awal atau modal perangsang sebesar antara 10 hingga 30 juta, agar BMT memulai operasi dengan syarat modal tersebut. Modal dapat berasala dari perorangan, lembaga, yayasan atau sumber lainnya, 4) P3B juga mencari modal-modal pendiri (simpanan pokok khusus semacam saham) masing-masing para pendiri perlu membuat komitmen tentang peranan masing-masing, 5) Jika calon pemodal-pemodal pendiri telah ada, maka dipilih pengurus yang dipercaya 5 orang yang akan mewakli pendiri dalam mengarahkan kebijakan BMT, 6) P3B atau pengurus jika telah ada mencari dan memilih calon pengelola BMT, 7) Mempersiapkan legalitas hukum dengan menghubungi kepala kantor/ dinas koperasi dan pembinaan usaha kecil di ibukota kabupaten/kota, 8) Melatih calon sebaiknya juga diikuti oleh salah

\footnotetext{
${ }^{11}$ Buchari Alma dan Doni Juni Priansa, Manajemen Bisnis Syari'ah, (Bandung: Alfbeta,2009), 18.

${ }^{12}$ M. Nur Rianto Al-Arif, Lembaga Keuangan Syariah, (Bandung: CV. Pustaka Setia, 2012), 324-325.

${ }^{13}$ Heri Sudarsono, Bank Dan Lembaga Keuangan Syariah, (Yogyakarta: Ekonisia, 2015), 116.
} 
satu pengurus dengan menghubungi PINBUK, 9) Melaksanakan persiapan-persiapan sarana kantor dan berkas administrasi yang diperlukan, 10) Modal awal BMT berasal dari modal para pendiri. Namun sejak awal anggota pendiri BMT harus terdiri minimal 20 orang yang mereka secara riil memberikan peran partisipasinya, masyarakat yang bersedia menjadi anggota BMT harus menyetorkan simpanan pokok Rp. 1.000.000,-/ anggota, 11) BMT didirikan dalam bentuk koperasi jasa keuangan syariah (KJKS) bila menginduk kepada koperasi serba usaha. BMT dapat didirikan dan dikembangkan dengan suatu proses legalitas hukum bertahap, dan 12) Organisasi BMT yang paling sederhana harus terdiri dari rapat anggota badan pengawas syariah, badan pengurus dan badan pengelola.

c. Penggunaan dana BMT

Penggunaan dana BMT merupakan upaya menggunakan dana BMT untuk keperluan operasinal yang dapat mengakibatkan berkembangnya BMT atau sebaliknya, jika penggunaannya salah. Pengalokasian dana BMT ini harus berorientasi untuk meningkatkan kesejahteraan anggota. Manajemen akan selalu dihadapkan pada dua persoalan, yakni bagaimana akan semaksimal mungkin mengalokasikan dana yang dapat memberikan pendapatan maksimal pula dan tetap menjaga kondisi keuangan sehingga dapat memenuhi kewajiban jangka pendeknya setiap saat. Dua kondisi ini dapat dicapai, jika manajemen mampu bertindak sesuai dengan landasan BMT yang sebenarnya. Untuk itu, pengalokasian dana BMT harus memperhatikan aspek sebagai berikut: ${ }^{14}$

1) Aman, artinya dana BMT dapat dijamin pengembaliannya.

2) Lancar, artinya perputaran dana dapat berjalan dengan cepat.

3) Menghasilkan, artinya pengalokasian dana harus dapat memberikan pendapatan maksimal.

4) Halal, artinya pengalokasian dana BMT harus pada usaha ang halal baik dari tinjauan hukum positif maupun agama.

5) Diutamakan untuk pengembangan usaha ekonomi anggota.

\section{Good Corporate Governance}

GCG adalah sebagai perangkat peraturan yang mengatur hubungan antara pemegang saham, pengurus (pengelola) perusahaan,pihak kreditur, pemerintah dan karyawan, serta para pemegang kepentingan internal dan eksternal lainnya yang berkaitan dengan hak-hak dan kewajiban mereka

${ }^{14}$ Muhammad Ridwan, Manajemen Bait al Mal Wa Tamwil, (Yogyakarta: UII Press, 2004), 56.

$168 \mid$ JURNAL LISAN AL-HAL 
atau dengan kata lain suatu sistem yang mengendalikan perusahaan dengan tujuan untuk menciptakan nilai tambah bagi semua pihak yang berkepentingan (stakeholder). ${ }^{15}$

Sedangkan menurut Worl Bank (Bank Dunia) GCG adalah suatu penyelenggaraan manajemen pembangunan yang solid dan bertanggung jawab yang sejalan dengan prinsip demokrasi dan pasar yang efisien, penghindaran salah alokasi dana investasi, dan pencegahan korupsi baik secara politik maupun administrative, menjalankan disiplin anggaran serta penciptaan legal and political framework bagi tumbuhnya aktivitas usaha. ${ }^{16}$

a. Tujuan Good Corporate Governance (GCG)

Dengan meningkatnya persaingan yang ketat untuk memperoleh modal, kecenderungan saat ini, lebih banyak dititik beratkan pada pelaksanaan Good Corporate Governance yang efektif. Pelaksanaan Good Corporate Governance yang sungguh-sungguh menjadi sangat vital bagi dunia usaha terutama untuk tujuan-tujuan: 1) Meningkatkan kemampuan bersaing mendapatkan modal di pasar global, 2) Mengurangi resiko perubahan yang bersifat tiba-tiba dan mendorong penanaman modal jangka panjang, 3) Memperkuat sector financial, dan 4) Memajukan manajemen yang bertanggung jawab dan kinerja financial yang solid. ${ }^{17}$

b. Prinsip-prinsip Good Corporate Governance (GCG)

Prinsip yang ada dalam Good Corporate Governance (GCG) adalah sebagau berikut: Pertama, Transparansi. Prinsip dasar dari transparansi ini untuk menjaga objektifitas dalam menjalankan program dalam perusahaan atau organisasi. Perusahaan atauorganisasi harus menyediakan informasi yang material dan relevan dengan cara mudah diakses dan dipahami oleh pemangku kepentingan. ${ }^{18}$ Dalam hal ini BMT harus memberikan kemudahan dalam pemberian informasi kepada pemangku kepentingan, serta kepada para nasabah, yaitu informasi yang tepat, akurat serta memadai.

Kedua, Akuntabilitas adalah kejelasan fungsi dan pelaksanaan pertanggung jawaban organ bank sehingga pengelolaannya berjalan

15 M. Arief Effendi, The Power of Good Corporate Governance Teori Dan implementasi, (Jakarta: Salemba Empat, 2009), 1.

${ }^{16}$ Eddi Wibowo, dkk, Memahami Good Corporate Government Governance dan Good Corporate Governance, (Jakarta: YPAPI, 2004), 86.

17 Muhammad Sadi Is, Hukum Perusahaan Di Indonesia, (Jakarta: Kencana, 2016), 226.

18Rahmani Timorita Yulianti, Good Corporate Governance Di Lembaga Zakat, (Yogyakarta: Kaukaba, 2016), 20. 
efektif. Ketiga, Pertanggungjawaban, adalah kesesuaian pengelolaan bank dengan peraturan perundang-undangan. ${ }^{19}$, Keempat, Professional yaitu memiliki kompetensi maupun bertindak objektif dan bebas dari pengaruh atau tekanan dari pihak manapun (independen) serta memiliki komitmen yang tinggi untuk mengembangkan bank syariah, Kelima, Kewajaran yaitu keadilan dan kesetaraan dalam mempengaruhi hak-hak stakeholder berdasarkan perjanjian dan perrundang-undangan yang berlaku. ${ }^{20}$

c. Indikator prinsip-prinsip GCG

Pertama, Prinsip transparansi meliputi: 1) Kemudahan mengakses informasi, 2) Ketersediaan informasi, 3) Kerahasiaan perusahaan, 40 Penyampaian kebijakan, dan 5) Visi dan misi perusahaan. Kedua, Prinsip akuntabilitas meliputi: 1) Perincian tugas dan tanggung jawab, 2) Kompetensi yang sesuai, 3) Sistem pengendalian internal, 4) Pengukuran kinerja, dan 5) Pelaksanaan tugas sesuai pedoman. Ketiga, Prinsip Pertanggung jawaban meliputi: 1) Kepatuhan hukum, 2) Tanggung jawab sosial, 3) Prinsip kehati-hatian, 4) Dominasi dan pengaruh, dan 5) Pelaksanaan tugas sesuai tanggung jawab. Keempat, Prinsip Profesional yaitu: 1) Dominasi dan pengaruh dan 2) Pelaksanaan tugas sesuai tanggung jawab. Kelima, Prinsip Kewajaran (fairness) yaitu: 1) Kesempatan berpendapat, 2) Kesetaraan kompensasi, dan 3) Kesempatan karyawan

\section{Kendala Menjalankan Good Corporate Governance}

Dalam penelitian yang dilakukan oleh mahasiswa program studi Magister Ilmu Hukum UNDIP Mujiburrahman, dengan judul "Implementasi kebijakan peraturan bank Indonesia N0.8/4/PBI/2006 Self Assessment Good Corporate Governance Pada Bank Go Public", dikemukakan bahwa dari 36 bank yang sudah go public, 11 bank mendapatkan predikat sangat baik, sedangkan 1 bank dengan predikat baik. Adapun bank-bank yang masih perlu perbaikan yaitu 5 bank mendapatkan predikat cukup baik dan 1 bank kurang baik. Dalam hal ini terdapat kendala yang dihadapi dalam implementasi self assessment Good Corporate Governance bagi Bank Go Public yaitu ada 2 faktor. Faktor eksternal dan internal. Kendala faktor eksternal dalam penerapan GCG adalah meliputi:

\footnotetext{
${ }^{19} \mathrm{Mal}$ An Abdullah, Corporate Governance Perbankan Syariah Di Indonesia, (Jogyakarta: Ar-Ruzz Media, 2010), 70-71.

20 Rachmadi Usman, Aspek Hukum Perbankan Syariah Di Indonesia (Jakarta: Sinar Grafika, 2014), 260.

$170 \mid$ JURNAL LISAN AL-HAL
} 
Pertama, Sistem hukum dan penegaknya yaitu: 1) Good governance dan standart profesionalisme, 2) Sosial value sistem. Kedua, Kendala internal dalam penerapan GCG yaitu: 1) Komitmen organ perusahaan dan budaya perusahaan, 2) Pemahaman SDM tentang GCG, dan 3) Kurang efektifitas sistem pengendalian internal.

Dari hambatan atau kendala yang ada hal atau upaya yang bisa dilakukan diantaranya adalah, dari faktor eksternal: 1) Regulasi yang mendukungimplementasi GCG dan disertai Law Enforcement, 2) Depolitisasi perusahaan dan mendorong agar lebih independen dan 3) Perbaikan GCG secara simultan.

Sedangkan upaya dalam faktor internal adalah: 1) Restrukturisasi internal dengan pembenahan budaya kerja dan perbaikan regulasi, 2) Komitmen kuat dari seluruh organ perusahaan dan panutan dan teladan dari top manajemen, dan 3) Implementasi secara simultan dan konsisten. ${ }^{21}$

\section{Implementasi Prinsip Good Corporate Governance (GCG) di KSPPS BMT Salafiyah Sukorejo Sumberejo Kec. Banyuputih Kab. Situbondo}

KSPPS BMT Salafiyah saat ini memiliki 4 kantor cabang dan 1 kantor pusat. Hal ini merupakan prestasi yang dimiliki KSPPS BMT Salafiyah karena bisa bermetamorfosis ke arah yang lebih baik dari tahun ke tahun. Salah satu hal yang berpengaruh dalam perkembangan KSPPS BMT adalah dengan cara menerapkan Good Corporate Governance (GCG). Dalam mengendalikan operasionalnya KSPPS BMT Salafiyah menggunakan dua pengendalian yaitu faktor eksternal dan faktor internal. Untuk faktor eksternal KSPPS BMT Salafiyah menggandenng para alumni Pondok Pesantren Salafiyah Syafi'iyah untuk memudahkan koordinasi dan memudahkan pemahaman visi misi KSPPS BMT Salafiyah. Sedangkan faktor internalnya adalah dengan menerapkan Good Corporate Governance (GCG). Adapun Good Corporate Governance (GCG) dalam penelitian ini adalah masalah:

a. Transparansi

Dalam prinsip transparansi ini, lembaga dituntut untuk transparan dalam pengelolaan operasionalnya. Di KSPPS BMT Salafiyah dalam menerapkan prinsip transparansi ini dengan caramenyediakan web yang langsung bisa di akses oleh anggota KSPPS. Web ini digunakan KSPPS BMT Salafiyah untuk memudahkan anggota memonitoring dan mendapatkan

${ }^{21}$ https://www.researchgate.net 
informasi tentang KSPPS. Bukan hanya itu KSPPS BMT Salafiyah juga menyediakan layanan langsung tatap muka yang dilayani oleh ketua KSPPS BMT Salafiyah pada waktu jam kerja. Hal lain yang dilakukan KSPPS dalam memberikan kemudahan akses kepada anggota dalam memperoleh informasi adalah dengan menyediakan pamphlet dan brosur kepada anggota untuk menambah pengetahuan tentang KSPPS BMT Salafiyah. Tidak berhenti disitu, KSPPS juga membentuk grup WA (WAG) khusus anggota supaya informasi bisa tersampaikan dengan mudah, dan juga kirtik dan saran disampaikan anggota digrup tersebut. Tak pelak juga KSPPS juga menugaskan petugas funding untuk bisa menyampaikan informasi kepada anggota apabila ada kebijakan atau informasi dari KSPPS. Di KSPPS para anggota. Ada juga hal yang dilakukan oleh KSPPS untuk menjaga keamanan KSPPS yaitu adanya kerahasiaan jumlah keuangan yang tidak bisa sembarang di akses, maka dari itu KSPPS menjaga dengan teguh apa yang menjadi rahasia perusahaan yaitu masalah jumlah keuangan.

Secara teori, prinsip dasar dari transparansi ini untuk menjaga objektifitas dalam menjalankan program dalam perusahaan atau organisasi. Perusahaan atau organisasi harus menyediakan informasi yang material dan relevan dengan cara mudah diakses dan dipahami oleh pemangku kepentingan. ${ }^{22}$ Sebuah lembaga keuangan dikatakan sudah menerapkan prinsip transparansi apabila menerapkan:

1) Kemudahan mengakses informasi. KSPPS, dalam memberikan kemudahan dalam mengakses informasi ini dengan cara menyediakan web yang bisa diakses anggota, menyediakan layanan langsung tatap muka yang dilayani oleh ketua setiap jam kerja,

2) Ketersediaan informasi. KSPPS juga menyediakan pamphlet dan brosur kepada anggota untuk menambah pengetahuan tentang KSPPS BMT Salafiyah, dan membentuk grup WA (WAG) khusus anggota supaya informasi bisa tersampaikan dengan mudah, dan juga kirtik dan saran disampaikan anggota dgrup tersebut.

3) Kerahasiaan perusahaan. KSPPS jumlah keuangan perusahaan menjadi hal yang rahasia, dan tidak bisa diakses secara terbuka.

4) Penyampaian kebijakan. Dalam masalah kebjakan ini KSPPS menggunakan jasa karyawan funding untuk menyampaikan kebijakan KSPPS.

${ }^{22}$ Rahmani Timorita Yulianti, Good Corporate Governance Di Lembaga Zakat, (Yogyakarta: Kaukaba, 2016), 20.

$172 \mid$ JURNAL LISAN AL-HAL 
5) Visi dan misi perusahaan. Mengenai visi dan misi perusahaan, yang menjadi visi misi KSPPS adalah terbangunnya dan berkembangnya ekonomi ummat dengan berlandaskan syariat Islam, terwujudnya budaya taawun dalam kebaikan dan ketakwaan di bidang sosial ekonomi. Sedangkan misinya adalah menerapkan dan memasyarakatkan syariat Islam dalam aktifitas ekonomi, menanamkan pemahaman bahwa sistem ekonomi syariat adalah Adil, Mudah, dan Maslahah, meningkatkan kesejahteraan ummat dan anggota, melakukan aktivitas ekonomi dengan budaa STAF (Shiddiq, Tabligh, Amanah, dan Fatonah). Dan di dalam visi misi itu terdapat isi yang menjelaskan bahwa KSPPS ingin menanamkan pemahaman bahwa sistem ekonomi syari'at adalah adil, mudah dan maslahah.

b. Prinsip Akuntabilitas

Selain prinsip transparansi ada juga prinsip akuntabilitas yang harus dijalankan oleh perusahaan. Dalam menerapkan prinsip akuntabilitas ini KSPPS melakukan teguran kepada karyawan yang kurang tanggung jawab terhadap pekerjaannya. Dan tentunya teguran itu diberikan kepada karyawan yang tidak menjalankan job description yang ada. Dalam job description tersebut sudah jelas apa yang menjadi hak dan kewajiban karyawan. Dan untuk mendapatkan karyawan yang berkompeten di bidangnya KSPPS melakukan penyeleksian karyawan secara bertahap yaitu adanya tes awal yang dilaksanakan pengurus, kemudian nama yang masuk nominasi akan diajukan ke kiai untuk diistikhorohkan. Dan untuk pengendalian internal, KSPPS melakukan pengendalian internal dengan cara semua pengurus dan karyawan dalam menjalankan tugasnya harus sesuai SOP. Sedangakan pengendalian keuangan diadakan laporan keuangan tiap seminggu sekali yang dilakukan kasir kepada bendahara kemudian laporan keuangan bulanan yang dilakukan bendahara kepada semua pengurus. Dan untuk pengendalian di kantor cabang pengurus melkukan kontrol sewaktu-waktu ke kontor cabang. Dan mengadakan audit ke kantor cabang (kwartal) tiap 4 bulan sekali.

KSPPS juga melakukan pengukuran kinerja karyawan dengan cara melihat kerajinan dan kedisiplinan karyawan dan akan diberikan reward supaya karyawan termotivasi untuk terus meningkatkan kinerjanya. Secara teori prinsip akuntabilitas adalah kejelasan fungsi dan pelaksanaan pertanggung jawaban organ bank sehingga pengelolaannya berjalan 
efektif.. ${ }^{23}$ Dan perusahaan atau lembaga keuangan dikatakan menerapkan prinsip akuntabilitas adalah:

1) Perincian tugas dan tanggung jawab. Dalam masalah ini di KSPPS melakukan teguran kepada karyawan yang kurang tanggung jawab terhadap pekerjaannya. Dan dalam menjalankan operasionalnya setiap karyawan diberi pemahaman teng job description masing-masing, disana jelas apa yang menjadi hak dan kewajiban para pengurus dan karyawan.

2) Kompetensi yang sesuai. Untuk mencari karywan yang kompeten, KSPPS melakukan penyeleksian karyawan secara bertahap yaitu adanya tes awal yang dilaksanakan pengurus, kemudian nama yang masuk nominasi akan diajukan ke kiai untuk diistikhorohkan. Dan untuk mengasah kemampuan karyawan yang ada KSPPS mengikutkan karyawan pelatihan yang diadakan dinas koperasi.

3) Sistem pengendalian internal. Sistem pengendalian internal ini sangat penting untuk diterapkan karena jika sistem terkendali operasional akan berjalan lancar, di KSPPS pengendaian internal nya dilakukan dengan cara semua pengurus dan karyawan dalam menjalankan tugasnya harus sesuai SOP. Sedangakan pengendalian keuangan diadakan laporan keuangan tiap seminggu sekali yang dilakukan kasir kepada bendahara kemudian laporan keuangan bulanan yang dilakukan bendahara kepada semua pengurus. Dan untuk pengendalian di kantor cabang pengurus melkukan kontrol sewaktu-waktu ke kontor cabang. Dan mengadakan audit ke kantor cabang (kwartal) tiap 4 bulan sekali.

4) Pengukuran kinerja. Pengukuran kinerja ini dilakukan dengan cara melihat kerajinan dan kedisiplinan karyawan dan akan diberikan reward supaya karyawan termotivasi untuk terus meningkatkan kinerjanya.

5) Pelaksanaan tugas sesuai pedoman. Dalam menjalankan tugasnya KSPPS menekankan karyawannya dalam menjalankan operasionalnya harus sesuai SOP yang ada, dan hal ini di KSPPS masuk dalam pengendalian internal. Karena jika dalam menjalankan tugasnya sesuai SOP yang ada maka lembaga akan mudah terarah dan terkendali.

c. Prinsip pertanggung jawaban

Dalam prinsip pertanggung jawaban ini perusahaan harus bisa mempertanggungjawabkan pengelolaannya. Hal yang dilakukan KSPPS dalam menerapkan prinsip pertanggung jawaban ini adalah dalam

${ }^{23} \mathrm{Mal}$ An Abdullah, Corporate Governance Perbankan Syariah Di Indonesia, (Jogyakarta: Ar-Ruzz Media, 2010), 70

$174 \mid$ JURNAL LISAN AL-HAL 
operasionalnya KSPPS mempunyai legalitas hukum dan patuh terhadap aturan-aturan dinas koperasi dengan cara melakukan RAB dan RAT. Dan untuk bentuk tanggung jawab KSPPS terhadap sosial KSPPS menjalankan tanggung jawab sosial dengan cara meningkatkan kualitas produk dan memperluas pembiayaan serta memberikan sembako tiap tahun kepada dhuafa, fakir miskin dan anak yatim.

Secara teori prinsip pertanggung jawaban ini adalah kesesuaian pengelolaan bank dengan peraturan perundang-undangan. ${ }^{24}$ Sebuah perusahaan atau lembaga keuangan dikatakan sudah menerapkan prinsip pertanggung jawaban ini jika:

1) Kepatuhan hukum. Dalam hal ini KSPPS patuh terhadap hukum karena dalam operasionalnya KSPPS emiliki badan hukum, SIUP dan NPWP, serta melakukan RAB dan RAT yang merupakan aturan dari dinas koperasi.

2) Tanggung jawab sosial. KSPPS melakukan tanggung jawab sosial dengan cara meningkatkan kualitas produk dan memperluas pembiayaanterbukti dengan banyaknya produk dan pembiayaan yang ditawarkan serta memberikan sembako tiap tahun kepada dhuafa, fakir miskin dan anak yatim.

3) Prinsip kehati-hatian. Dalam prinsip kehati-hatian ini KSPPS cukup berhati-hati dalam menajalankan operasionalnya terutama dalam pengelolaan keuangan aitu adanya laporan keuangan mingguan yang dilakukan kasir kepada bendahara, adanya laporan keuangan laporan keuangan bulanan yang dilakukan bendahara kepada pengurus, adanya audit sewaktu-waktu yang dilakuakan ke kantor cabang, adanya audit kwartal yang dilakukan 4 bulan sekali ke kantor cabang.

4) Dominasi dan pengaruh. Tidak ada yang mendominasi dan pengaruh karena operasional dijalankan sesuai SOP.

5) Pelaksanaan tugas sesuai tanggung jawab. Dalam melaksanakan tanggung jawab para pengurus dan karyawan menjalankan tugasnya masing-masing dengan mengacu pada job description yang ada.

d. Prinsip Profesionalitas

Prinsip ini menekankan pada pengurus dan karyawan untuk berkompeten/ professional dalam menjalankan tugasnya. KSPPS menjalankan prinsip ini dengan cara melakukan penyeleksian karyawan secara ketat dan istikhoroh kiai. Dan dalam menempatkan jabatan pengurus sesuai hasil istikhoroh kiai. Dalam menjalankan operasionalnya

${ }^{24}$ Mal An Abdullah, Corporate Governance Perbankan Syariah Di Indonesia, (Jogyakarta: Ar-Ruzz Media, 2010), 70-71. 
tidak ada yang mendominasi karena menjalankan operasional sesuai SOP. Sedangkan seperti yang di sampaikan di atas bahwa alumni memiliki pengaruh yang cukup besar dalam pengembangan KSPPS BMT Salafiyah.

Secara teori prinsip profesionalitas adalahmemiliki kompetensi maupun bertindak objektif dan bebas dari pengaruh atau tekanan dari pihak manapun (independen) serta memiliki komitmen yang tinggi untuk mengembangkan bank syariah. Lembaga keauangan dikatakan menjalankan prinsip ini apabila:

1) Dominasi dan pengaruh. KSPPS menjalankan prinsip ini dengan cara melakukan penyeleksian karyawan secara ketat dan istikhoroh kiai. Dan dalam menempatkan jabatan pengurus sesuai hasil istikhoroh kiai. Sedangkan untu pengaruh alumni memiliki peran yang cukup berpengaruh dalam pengembangan KSPPS.

2) Pelaksanaan tugas sesuai tanggung jawab yaitu melaksanakan tugas sesuai SOP

e. Kewajaran/fairness

Fair merupakan prinsip yang harus dilakukan dalam lembaga keuangan. Di KSPPS Semua anggota bebas mengemukakan pendapat ketika RAT serta memberikan kesempatan yang sama kepada semua karyawan.

Secara teori fairness adalah keadilan dan kesetaraan dalam mempengaruhi hak-hak stakeholder berdasarkan perjanjian dan perundang-undangan yang berlaku. ${ }^{25}$ Prinsip fairness memiliki ketentuanketentuan sebagai berikut:

1) Kesempatan berpendapat. Di KSPPS semua anggota bebas mengajukan pendapatnya ketika RAT.

2) Kesetaraan kompensasi. Kompensasi diberikan kepada anggota yang rajin membayar angsuran dan karyawan yang memiliki kedisiplinan yang tinggi.

3) Kesempatan karyawan. Karyawaan mendapatkan kesempatan yang sama karena kenaikan jabatan ditentukan oleh hasil istikhoroh kiai/pengasuh Pondok Pesantren Salafiyah Syafi'iyah.

${ }^{25}$ Rachmadi Usman, Aspek Hukum Perbankan Syariah Di Indonesia (Jakarta: Sinar Grafika, 2014), 260.

176 JURNAL LISAN AL-HAL 


\section{Kendala Dalam Mengimplementasikan Good Corporate Governance di KSPPS BMT Salafiyah Sukorejo Sumberejo Kec. Banyuputih Kab. Situbondo}

Setiap lembaga sudah barang tentu memiliki kendala dalam menjalankan operasionalnya, begitu juga di KSPPS BMT Salafiyah. Dalam menjalankan operasionalnya kendala yang ditemui KSPPS BMT Salafiyah adalah masalah kedisiplinan karyawan yang naik turun. Ada dua faktor ang menjadi masalah dalam mengimplementasikan GCG ini yaitu faktor eksternal dan internal. Di KSPPS tidak ada faktor eksternal yang menjadi kendala dalam mengimplementasikan GCG. Kendala itu muncul dari faktor internal, yaitu masalah yang muncul dari dalam lembaga itu sendiri, seperti pasang surutnya kedisiplinan karyawan. Jika pemahaman karyawan terhadap GCG, tidak menjadi kendala karena para karyawan sebenarnya sudah menerapkan prinsip-prinsip GCG ini. Namun dari kendala tersebut, upaya dilakukan oleh KSPPS BMT Salafiyah dalam meningkatkan kedisiplinan karyawan adalah dengan cara membuat tata tertib kepada karyawan dengan ketentuan karyawan wajib hadir ke kantor sebelum jam 8 pagi. Dan upaya lainnya adalah dengan memberikan reward kepada karyawan yang memiliki kedisiplinan tinggi supaya terus termotivasi untuk selalu disiplin dan bisa memberikan energy positif kepada teman se profesi.

\section{Simpulan}

Pertama, Implementasi Good Corporate Governance (GCG) di KSPPS BMT Salafiyah Sukorejo. Di KSPPS BMT Salafiyah dalam menjalankan operasionalnya dengan cara menerapkan 5 prinsip GCG yaitu transparansi, akuntabilitas, pertanggung jawaban, profesionalitas dan kewajaran (fairness). Dalam menerapkan prinsip transparansi KSPPS BMT Salafiyah menyediakan web, layanan tatap muka oleh ketua di jam kerja, pamphlet dan brosur, Wa Grup (WAG), Penyampaian informasi dan kebijakan melalui petugas funding, serta Menjaga dengan teguh apa yang menjadi rahasia perusahaan.

Dalam menerapkan prisip akuntabilitas KSPPS menerapkan teguran kepada karyawan yang kurang tanggung jawab, Job Description jelas, perekrutan karyawan secara selektif, semua pengurus dan karyawan dalam menjalankan tugasnya harus sesuai SOP, laporan keuangan dilakukan secara mingguan dan bulanan, Kontrol sewaktu-waktu ke kontor cabang, audit ke kantor cabang (kwartal) tiap 4 bulan sekali, pengukuran kinerja karyawan dilihat dari kerajinan dan kedisiplinan

Dalam menerapkan prinsip pertanggung jawaban KSPPS memiliki

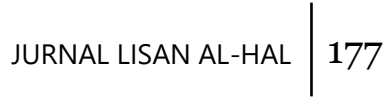


legalitas hukum, melakukan RAB dan RAT, menjalankan tanggung jawab sosial dengan cara meningkatkan kualitas produk dan memperluas pembiayaan serta melakukan pemberian sembako tiap tahun kepada duafa, fakir miskin dan anak yatim. Untuk mencetak pengelola yang handal KSPPS melakukan seleksi karyawan yang ketat, pelatihan bagi karyawan yang ada, penempatan jabatan sesuai istikhoroh kiai, operasional sesuai SOP, Menggandeng alumni dalam menjalankan operasionalnya. Untuk menjaga agar KSPPS selalu fair terhadap anggota, Semua anggota bebas mengemukakan pendapat ketika RAT, adanya kompensasi bagi karyawan yang rajin dan anggota yang rajin membayar angsuran dan memberikan kesempatan yang sama kepada semua karyawan.

Kedua, Kendala yang dihadapi dalam menerapkan Good Corporate Governance (GCG) di KSPPS BMT Salafiyah Sukorejo. Untuk kendala yang dihadapi dalam menerapkan GCG ini KSPPS BMT Salafiyah mengalami kendala di faktor internal yaitu pasang surutnya kedisiplinan karyawan dalam menjalankan tugas atau kewajibannya, upaya yang dilakukannya adalah dengan menerapkan tata tertib ke karyawan untuk datang ke kantor sebelum jam 8 dan pemberian reward kepada karyawan yang memiliki kedisiplinan tinggi.

\section{DAFTAR PUSTAKA}

Abdullah, Mal An, Corporate Governance Perbankan Syariah Di Indonesia, Jogyakarta: Ar-Ruzz Media, 2010.

Alma, Buchari dan Doni Juni Priansa, Manajemen Bisnis Syari'ah, Bandung: Alfbeta. 2009.

Arief Effendi, M., The Power Of Good Corporate Governance Teori Dan implementasi, Jakarta: Salemba Empat. 2009.

Cadbury, Komite, The Business Roundtable, Statement Untuk Corporate Governance, Washington DC:tnp, 1 dalam Mishardi Wilamarta, 40 dan dituangkan Hana Septi Kuncaraningsih dan M. Rasid Ridla, Good Corporate Governance Dalam Meningkatkan Kepuasan Muzakki di Badan Amil Zakat Nasional, 1997.

Hibat, Khoirul, Analisis Penerapan Good Corporate Governance (GCG) Pada Lembaga Keuangan Syariah Serta Pengaruhnya Terhadap Tingkat Pengembalian Pembiayaan (Studi Kasus BMT As Salam Kras Kediri), Kediri: 2018.

K Lubis, Suhrawardi, Hukum Ekonomi Islam, Jakarta: Sinar Grafika, 2000. Nur Islamiah, Elin, Penerapan Prinsip-prinsip Good Corporate Governance 
(GCG) Pada PT. ASDP Indonesia Ferry (Persero) Cabang MerakBanten, Serang: 2018.

Rianto Al Arif, M. Nur, Dasar-Dasar Pemasaran Bank Syariah, Bandung: Alfabeta. 2010.

Rianto Al-Arif, M. Nur, Lembaga Keuangan Syariah, Bandung: CV. Pustaka Setia, 2012.

Ridwan, Muhammad, Manajemen Bait al Mal Wa Tamwil, Yogyakarta: UII Press, 2004.

Sadils, Muhammad, Hukum Perusahaan Di Indonesia, Jakarta: Kencana, 2016.

Setia, Muda dan Zulkifli, Pengaruh Penerapan Corporate Governanace (GCG) Dan Budaya Organisasi Pengelolaan Zakat Terhadap Motivasi Pembayaran zakat Penghasilan di DIY, Jurnal Kajian Bisnis Vol.2, No. 1, Januari 2018.

Subana, M, Dasar- Dasar Penelitian Karya Ilmiah, Bandung: Pustaka Setia. 2001.

Sudarsono, Heri, Bank Dan Lembaga Keuangan Syariah, Yogyakarta: Ekonisia, 2004.

Sudarsono, Heri, Bank Dan Lembaga Keuangan Syariah, Yogyakarta: Ekonisia, 2015.

Timorita Yulianti, Rahmani, Good Corporate Governance di Lembaga Zakat, Yogyakarta: Kaukaba, 2016.

Tim Penyusun KBBI, Jakarta, Balai Pustaka, 2002

https://www.researchgate.net

Umam, Khaerul, Manajemen Perbankan Syariah, Bandung: Pustaka Setia. 2013,

Usman,Rachmadi, Aspek Hukum Perbankan Syariah Di Indonesia, Jakarta: Sinar Grafika. 2014.

Wibowo, Eddi dkk, Memahami Good Corporate Government Governance dan Good Corporate Governance, Jakarta: YPAPI, 2004. 
"Prinsip Good Corporate Governance"

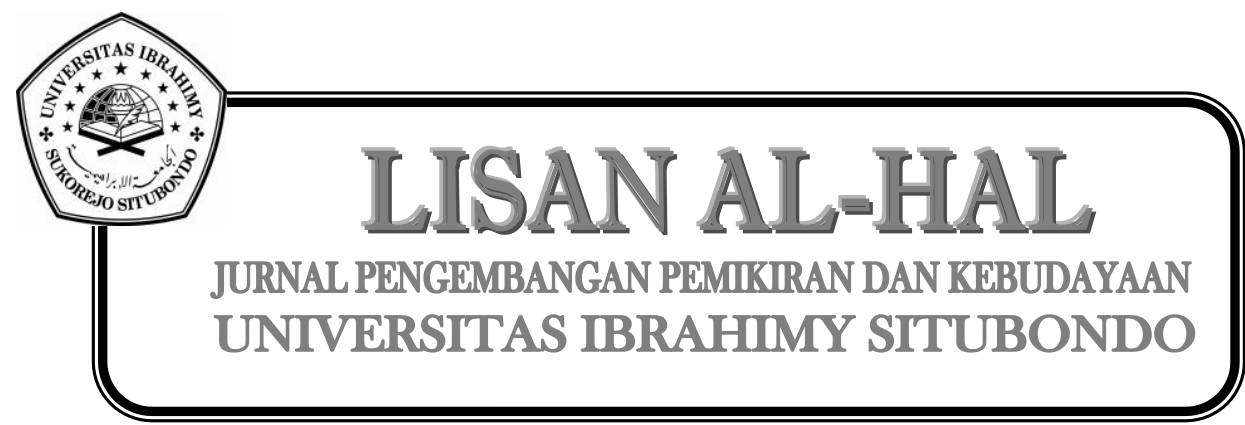

180 JURNAL LISAN AL-HAL 